\title{
Composition of emergency medical services teams and the problem of specialisation of emergency medical services physicians in the opinions of occupationally active paramedics
}

\section{Skład zespołu ratownictwa medycznego i problem specjalizacji lekarzy systemu według czynnych zawodowo ratowników medycznych}

\section{Dorota Rębak}

Department of Surgery and Surgical Nursing with Research Laboratory, Institute of Nursing and Obstetrics, Faculty of Health Sciences, Jan Kochanowski University, Kielce, Poland

Head of the Department: Prof. Stanisław Głuszek MD, PhD

Studia Medyczne 2014; 30 (4): 247-253

DOI: $10.5114 / m s .2014 .47923$

Key words: paramedics, emergency medical services system physician, specialisation in emergency medicine.

Słowa kluczowe: ratownik medyczny, lekarz systemu, specjalizacja z medycyny ratunkowej.

\begin{abstract}
Introduction: Emergency medicine includes prevention, prehospital care, specialised treatment, rehabilitation, and education. Aim of the research: The objective of the analysis was to determine the opinions of paramedics concerning the problem of the composition of emergency medical services (EMS) teams and specialisation of EMS system physicians according to their education level and sense of coherence.

Material and methods: The study was conducted among 336 occupationally active paramedics working in EMS teams delivering prehospital care in selected units in Poland. The study was conducted at Ambulance Stations and in Hospital Emergency Departments, which within their structure had an out-of-hospital EMS team. The study was conducted by the method of a diagnostic survey, and the research instrument was the Orientation to Life Questionnaire SOC-29 and a questionnaire designed by the author.

Results: The respondents who had licentiate education relatively more frequently indicated paramedics with licentiate education level as persons most suitable to undertake medical actions $(26.32 \%)$ rather than physicians $(21.05 \%)$. Paramedics with 2-year post-secondary school education relatively more often mentioned physicians (33.07\%) than those with licentiate education (17.32\%). As many as $89.58 \%$ of the paramedics reported the need for a physician in the composition of the EMS team delivering prehospital care, while only $10.42 \%$ of them expressed an opinion that there should be teams composed of paramedics only. According to $30.65 \%$ of respondents, EMS team delivering prehospital care should include a physician with the specialty in emergency medicine, whereas $8.04 \%$ of respondents reported the need for a physician, irrespective of specialisation. However, $42.56 \%$ of the paramedics expressed an opinion that a physician is needed only in a specialist team with a specialisation in emergency medicine. The opinions of the paramedics concerning the need for a physician in an EMS team delivering prehospital care, which also considers the problem of specialisation, significantly differ statistically according to the sense of manageability, meaningfulness, and global sense of coherence.

Conclusions: The assessment of the composition of a paramedical team depends on the level of education of paramedics. The need for a doctor in a team, as well as for specialization in emergency medicine, has been proven by the levels of obtained SOC and its components, together with the relations observed in groups assessing the studied problems.
\end{abstract}

\section{Streszczenie}

Wprowadzenie: System medycyny ratunkowej obejmuje zapobieganie, opiekę przedszpitalną, leczenie specjalistyczne, rehabilitację oraz edukację.

Cel pracy: Ustalenie stanowiska ratowników medycznych w zakresie składu zespołów ratownictwa medycznego i specjalizacji lekarza systemu w zależności od wykształcenia i poczucia koherencji ratowników.

Materiał i metody: Badania przeprowadzono wśród 336 ratowników medycznych czynnych zawodowo, pracujących $\mathrm{w}$ wyjazdowych zespołach ratownictwa medycznego w losowo wybranych placówkach na terenie Polski. Do badania wykorzystano metodę sondażu diagnostycznego, a narzędziem badawczym był Kwestionariusz orientacji życiowej SOC-29 i autorski kwestionariusz ankiety.

Wyniki: Badani z wykształceniem licencjackim stosunkowo więcej razy wskazali ratowników medycznych z wykształceniem policealnym osoby odpowiednie do podejmowania czynności medycznych $(26,32 \%)$ niż lekarzy (21,05\%). Ratownicy medyczni z dwuletnim wykształceniem stosunkowo więcej razy wskazali na lekarzy (33,07\%) niż na ratowników medycznych 
z wykształceniem licencjackim (17,32\%). Ratownicy medyczni w 89,58\% wskazali potrzebę udziału lekarza w składzie zespołu wyjazdowego. Jedynie 10,42\% uważa, że powinny funkcjonować zespoły paramedyczne. Według 30,65\% badanych w skład zespołu wyjazdowego powinien wchodzić lekarz ze specjalizacją z medycyny ratunkowej, a 8,04\% respondentów potwierdza potrzebę udziału lekarza bez względu na specjalizację. Jednak 42,56\% ratowników medycznych uważa, że lekarz potrzebny jest tylko w zespole specjalistycznym ze specjalizacją z medycyny ratunkowej. Opinia ratowników medycznych o potrzebie udziału lekarza w zespole wyjazdowym, uwzględniająca również problem specjalizacji, jest istotnie statystycznie zróżnicowana w zależności od poczucia zaradności, sensowności i ogólnego poczucia koherencji.

Wnioski: Ocena składu zespołu ratownictwa medycznego zależy od stopnia wykształcenia ratowników. Potrzebę lekarza w zespole i specjalizacji z medycyny ratunkowej potwierdzają uzyskane poziomy SOC i jej składowych oraz zachodzące zależności w grupach oceniających badane kwestie.

\section{Introduction}

Emergency medicine is a specialty based on the knowledge and skills required for the prevention, diagnosis, and management of urgent and emergency aspects of illness and injury affecting patients of all age groups, with a full spectrum of undifferentiated physical and behavioural disorders [1].

The longest possible preservation of life occupies a primary position among the strivings of contemporary man. The reduction in mortality due to injuries and sudden emergencies is one of the methods to obtain this goal. This may be achieved by the creation of an effective system of action in emergency states threatening health and life, i.e. the system of emergency medical services [2].

The system of emergency medical services covers prevention, prehospital care, specialist treatment, rehabilitation, and education [3].

The units of the system in which medical care services are provided within the emergency medical procedures undertaken are as follows: hospital emergency departments; emergency medical services, including air emergency medical services [4].

In the structure of the emergency medical services (EMS) the following teams are distinguished as follows: (1) specialist teams consisting of at least 3 persons authorised to perform emergency medical procedures, including an EMS system physician and nurse, or a paramedic; (2) basic teams consisting of at least two persons authorised to perform emergency medical tasks, including an EMS system nurse, or a paramedic; (3) air EMS team consisting of at least 3 persons, including a professional pilot and a paramedic or an EMS system nurse and physician [4].

According to the concept of salutogenesis by Antonovsky, the sense of coherence (SOC) is defined as a relatively constant orientation delineating a specified way of perceiving the world as predictable, manageable, and worthy of effort and engagement [5]. This generalised, emotional-cognitive way of perceiving the world contains three components that are inseparably combined. Comprehensibility is the perception of the inflowing information as understandable, ordered, coherent, and clear. Manageability is the perception of resources at the disposal of an individual, which allows the satisfaction of the requirements posed. Meaningfulness is the sense that there are important domains of life that are worthy of emotional engagement and devotion of energy [5].

\section{Aim of the research}

The objective of the study was determination of the opinions of paramedics concerning the problem of staffing of an EMS team and the specialisation of an EMS system physician, according to their education level and sense of coherence.

\section{Material and methods}

The presented study is a part of a wider project concerning the analysis of the occupational life of paramedics in light of the sense of coherence.

The study was conducted during the period from June-October 2010 among 336 occupationally active paramedics working in EMS teams in selected facilities in Poland, in Ambulance Stations, and in Hospital Emergency Units, which included EMS teams in their structure. In Hospital Emergency Departments paramedics were examined who worked in EMS teams in out-of-hospital conditions. Consent for the study was obtained from the Bioethics Commission at the Department of Health Sciences, Jan Kochanowski University in Kielce on 4 June 2010, No. 22/2010.

The study group consisted of 292 males (86.90\%) and 44 females (13.10\%). As many as 235 (90.73\%) males and $24(9.27 \%)$ females had post-secondary school education, while $57(74.03 \%)$ males and 20 (25.97\%) females had completed $1^{\text {st }}$-degree university studies (licentiate). In the study group, graduates of post-secondary schools dominated.

The study was carried out by the method of a diagnostic survey, a research instrument - the Orientation to Life Questionnaire SOC-29 [6] - and a questionnaire designed by the author.

The SOC consists of 29 items in three subscales, equivalent to three components of the sense of coherence: comprehensibility, meaningfulness, and manageability. Respondents assessed the validity of each statement with respect to themselves and their life according to a 7-point scale, e.g. 'Life is from: 1 very interesting to 7 - monotonous'. The sum of the answers, according to the key, allows the determina- 
tion of the SOC and its three components [5]. Mean values of the sense of coherence and its components were calculated based on data obtained in individual groups with consideration of the aspects examined. These data were statistically analysed.

The questionnaire form contained 33 open or semi-open questions covering various aspects of the occupational activity of paramedics. Some of the results of research obtained were used within the scope of problems undertaken in the presented study.

\section{Statistical analysis}

The research material was subjected to statistical analysis using the SPSS 14 (Statistical Package for the Social Sciences) software. The following tests were applied: $\chi^{2}$ test for analysis of relationship between qualitative questions; analysis of variance ANOVA - for the analysis of relationship between qualitative questions with three or more categories and quantitative variables. Ryan-Einot-Gabriel-Welch $F$ test was used as a post-hoc procedure.

The following levels of statistical significance were adopted: $p>0.05$ - lack of statistical significance; $p<$ 0.05 - statistical significance; $p<0.01$ - high statistical significance. With the lack of statistical significance a calculated $p$ value was provided.

\section{Results}

Analysis of the results obtained (Table 1) showed that statistically significant differences pertained to opinions concerning the team member best predisposed to the undertaking of emergency life-saving medical procedures, according to their education $\left(\chi^{2}(2)=38.61 ; p<0.001\right)$. A group of paramedics with licentiate education level indicated people with 3 -year education (52.63\%). The group of paramedics with post-secondary school education considered those with 2-year education as the most suitable for undertaking life-saving procedures (49.61\%). Respondents with licentiate education level relatively more frequently mentioned paramedics with post-secondary school education as the persons most suited to undertake medical procedures $(26.32 \%)$ rather than physicians (21.05\%). Paramedics who had 2-years education relatively more often indicated physicians (33.07\%), compared to paramedics with licentiate education $(17.32 \%)$.

No statistically significant differences were observed between opinions concerning the need for a physician in the EMS team delivering prehospital care with respect to the education possessed by paramedics $\left(\chi^{2}(4)=0.81 ; p=0.938\right)$. As many as $89.58 \%$ of paramedics reported the need to include a physician in an out-of-hospital EMS team. Only $10.42 \%$ considered that teams composed of paramedics only should function (Table 2). However, specialisation of a physician and the type of team seems to be important (Table 2). According to the opinions of $30.65 \%$ of respondents, a physician with specialisation in emergency medicine should be included in a team, and $8.04 \%$ of respondents mentioned the need for a physician irrespective of specialisation. Nevertheless, $42.56 \%$ of paramedics expressed an opinion that a physician is needed only in the specialist team, and they should have specialisation in emergency medicine whereas $8.33 \%$ of respondents considered that the physician should be included in a specialist team, irrespective of specialisation.

The respondents' SOC level was evaluated and its components described (Tables 3-5).

In the study group, no differences were observed in the evaluation of the member of the team most predisposed for undertaking life-saving procedures (Table 3). The highest level of global SOC - 145.09 - and its components (sense of comprehensibility - 49.01, sense of manageability - 51.55, and sense of meaningfulness - 44.53) was obtained in the group indicating a physician as the person most predisposed for undertaking life-saving procedures. Slightly lower levels were obtained in the group of respondents who mentioned a paramedic with post-secondary education and, subsequently, a paramedic with licentiate education (Table 3 ).

Analysis of variance ANOVA was applied to investigate differences between groups concerning the sense of coherence and the evaluations by the para-

Table 1. Evaluations concerning the member of the EMS team best predisposed for undertaking life-saving procedures

\begin{tabular}{|lcccccc|}
\hline $\begin{array}{l}\text { Answer to the question: } \\
\text { In your opinion, which member of the EMS team is best } \\
\text { predisposed for undertaking life saving procedures? }\end{array}$ & $\begin{array}{c}\text { Gost-secondary } \\
\text { school }\end{array}$ & Licentiate & \multirow{2}{*}{ Total } \\
\cline { 2 - 7 } & $n$ & $\%$ & $n$ & $\%$ & \\
Paramedic who completed 2-year post-secondary school & 126 & 49.61 & 20 & 26.32 & 146 & 44.24 \\
Paramedic who completed 3-year licentiate studies & 44 & 17.32 & 40 & 52.63 & 84 & 25.45 \\
Physician & 84 & 33.07 & 16 & 21.05 & 100 & 30.30 \\
Total & 254 & 100.00 & 76 & 100.00 & 330 & 100.00 \\
\hline
\end{tabular}


Table 2. Opinions concerning the need for inclusion of a physician in an EMS team delivering prehospital care

\begin{tabular}{|c|c|c|c|c|c|c|}
\hline \multirow{3}{*}{$\begin{array}{l}\text { Answer to the question: } \\
\text { In your opinion, should physicians be included in an EMS } \\
\text { team delivering prehospital care? }\end{array}$} & \multicolumn{4}{|c|}{ Group } & \multicolumn{2}{|c|}{ Total } \\
\hline & \multicolumn{2}{|c|}{$\begin{array}{l}\text { Post-secondary } \\
\text { school }\end{array}$} & \multicolumn{2}{|c|}{ Licentiate } & \multirow{2}{*}{$n$} & \multirow{2}{*}{$\%$} \\
\hline & $n$ & $\%$ & $n$ & $\%$ & & \\
\hline $\begin{array}{l}\text { Yes, but only after completing specialisation in emergency } \\
\text { medicine }\end{array}$ & 79 & 30.50 & 24 & 31.17 & 103 & 30.65 \\
\hline Yes, they are needed irrespective of specialisation & 21 & 8.11 & 6 & 7.79 & 27 & 8.04 \\
\hline $\begin{array}{l}\text { Yes, they are needed only in specialist teams with } \\
\text { specialisation in emergency medicine }\end{array}$ & 109 & 42.08 & 34 & 44.16 & 143 & 42.56 \\
\hline $\begin{array}{l}\text { Yes, they are needed only in specialist teams irrespective } \\
\text { of specialisation }\end{array}$ & 21 & 8.11 & 7 & 9.09 & 28 & 8.33 \\
\hline No, only paramedic teams should provide services & 29 & 11.20 & 6 & 7.79 & 35 & 10.42 \\
\hline Total & 259 & 100.00 & 77 & 100.00 & 336 & 100.00 \\
\hline
\end{tabular}

Table 3. Comparison of mean values of the sense of coherence in groups evaluating the person best predisposed for undertaking life-saving procedures. Analysis of variance for differences between groups

\begin{tabular}{|c|c|c|c|c|c|c|c|c|}
\hline \multirow[t]{3}{*}{ Dependent variables } & \multicolumn{6}{|c|}{$\begin{array}{l}\text { Person best predisposed for undertaking life-saving } \\
\text { procedures }\end{array}$} & \multirow[t]{3}{*}{$\begin{array}{l}\text { Value } \\
\text { of } F\end{array}$} & \multirow[t]{3}{*}{$\begin{array}{c}\text { Value } \\
\text { of } p\end{array}$} \\
\hline & \multicolumn{2}{|c|}{$\begin{array}{l}\text { Paramedic with } \\
\text { post-secondary } \\
\text { school education }\end{array}$} & \multicolumn{2}{|c|}{$\begin{array}{l}\text { Paramedic } \\
\text { with licentiate } \\
\text { education }\end{array}$} & \multicolumn{2}{|c|}{ Physician } & & \\
\hline & $\bar{x}$ & SD & $\bar{x}$ & SD & $\bar{x}$ & SD & & \\
\hline Sense of comprehensibility & 48.25 & 9.93 & 47.45 & 8.13 & 49.01 & 9.04 & 0.65 & 0.522 \\
\hline Sense of manageability & 50.06 & 8.37 & 49.42 & 7.98 & 51.55 & 8.72 & 1.63 & 0.198 \\
\hline Sense of meaningfulness & 43.36 & 7.32 & 42.57 & 7.16 & 44.53 & 7.51 & 1.68 & 0.187 \\
\hline Global sense of coherence SOC & 141.67 & 22.50 & 139.44 & 19.68 & 145.09 & 22.55 & 1.59 & 0.206 \\
\hline
\end{tabular}

medics of the place of a physician in an EMS team (Tables 4, 5).

Analysis of the results obtained allows the presumption that the opinions of paramedics concerning the need for inclusion of a physician in an EMS team delivering prehospital care, and about the problem of specialisation, significantly differ statistically according to the sense of manageability, meaningfulness, and global sense of coherence. Relationships were noted between the following:

- the sense of manageability $(p=0.012)$, the sense of meaningfulness $(p=0.014)$ and global sense of coherence $(p=0.008)$, and paramedics opinions concerning the need for inclusion of a physician in the team, which means that paramedics who consider that physicians are needed in the team, irrespective of their specialisation, have a lower sense of manageability, meaningfulness, and general sense of coherence, compared to those who report the need for a physician possessing specialisation in emergency medicine only in specialist teams, and with respect to those who consider that the teams should be composed only of paramedics;

- the sense of meaningfulness $(p=0.014)$ and global sense of coherence $(p=0.008)$ and the need for inclusion of a physician in the team, which means that the paramedics indicating the need for a physician only in specialist teams, irrespective of specialisation, have a lower sense of meaningfulness and lower global sense of coherence, compared to the respondents who preferred teams composed of paramedics only; - a lower sense of meaningfulness $(p=0.014)$ in paramedics who reported the need for inclusion of a physician only in a specialist team, irrespective of specialisation, compared to those with a higher sense of meaningfulness who mentioned the need for specialisation in emergency medicine among physicians in specialist teams; 
Table 4. Comparison of mean values of the sense of coherence and its components in groups evaluating the need for a physician in an EMS team delivering prehospital care

\begin{tabular}{|c|c|c|c|c|}
\hline Dependent & & Answer & $\bar{x}$ & SD \\
\hline \multirow{5}{*}{$\begin{array}{l}\text { Sense of } \\
\text { comprehensibility }\end{array}$} & 1 & Yes, after completing specialisation in emergency medicine & 47.29 & 8.90 \\
\hline & 2 & Yes, needed irrespective of specialisation & 45.04 & 8.91 \\
\hline & 3 & $\begin{array}{l}\text { Yes, needed only in specialist teams with specialisation in emergency } \\
\text { medicine }\end{array}$ & 49.37 & 9.18 \\
\hline & 4 & Yes, needed only in specialist teams irrespective of specialisation & 47.39 & 8.97 \\
\hline & 5 & No, only paramedic teams should provide services & 49.91 & 10.33 \\
\hline \multirow{5}{*}{$\begin{array}{l}\text { Sense of } \\
\text { manageability }\end{array}$} & 1 & Yes, after completing specialisation in emergency medicine & 49.56 & 8.63 \\
\hline & 2 & Yes, needed irrespective of specialisation & 46.93 & 6.65 \\
\hline & 3 & $\begin{array}{l}\text { Yes, needed only in specialist teams with specialisation in emergency } \\
\text { medicine }\end{array}$ & 51.31 & 8.01 \\
\hline & 4 & Yes, needed only in specialist teams irrespective of specialisation & 48.39 & 8.60 \\
\hline & 5 & No, only paramedic teams should provide services & 53.20 & 9.42 \\
\hline \multirow{5}{*}{$\begin{array}{l}\text { Sense of } \\
\text { meaningfulness }\end{array}$} & 1 & Yes, after completing specialisation in emergency medicine & 42.48 & 7.43 \\
\hline & 2 & Yes, needed irrespective of specialisation & 41.07 & 6.52 \\
\hline & 3 & $\begin{array}{l}\text { Yes, needed only in specialist teams with specialisation in emergency } \\
\text { medicine }\end{array}$ & 44.69 & 6.90 \\
\hline & 4 & Yes, needed only in specialist teams irrespective of specialisation & 41.96 & 7.71 \\
\hline & 5 & No, only paramedic teams should provide services & 45.46 & 7.98 \\
\hline \multirow{5}{*}{$\begin{array}{l}\text { Global sense of } \\
\text { coherence SOC }\end{array}$} & 1 & Yes, after completing specialisation in emergency medicine & 139.32 & 21.42 \\
\hline & 2 & Yes, needed irrespective of specialisation & 133.04 & 17.81 \\
\hline & 3 & $\begin{array}{l}\text { Yes, needed only in specialist teams with specialisation in emergency } \\
\text { medicine }\end{array}$ & 145.37 & 21.23 \\
\hline & 4 & Yes, needed only in specialist teams irrespective of specialisation & 137.75 & 23.13 \\
\hline & 5 & No, only paramedic teams should provided services & 148.57 & 24.26 \\
\hline
\end{tabular}

- the lower global sense of coherence $(p=0.008)$ in paramedics who indicated the need for a physician, irrespective of specialisation, and those who preferred teams composed of paramedics only.

\section{Discussion}

On 31 December 2012 there came into effect an amendment of the Act in the Matter of Emergency Medical Services. This Act provides the criteria which must be satisfied by physicians working in EMS specialist teams.

This amendment was necessary with respect to the concern that after 1 January 2013 more than 600 physicians would lose their authorisation indispensable for work in emergency medical services teams [7].

The Act in the Matter of State Emergency Medical Services specifies, among other things, the composition of specialist emergency medical services teams, and states that from 1 January 2013, only the EMS physician and EMS nurse or a paramedic are authorised for the provision of services [8].
Table 5. Analysis of variance in groups differing with respect to opinions concerning the need for inclusion of a physician in an EMS team delivering prehospital care

\begin{tabular}{|lccc|}
\hline $\begin{array}{l}\text { Dependent } \\
\text { variables }\end{array}$ & $\begin{array}{c}\text { Value } \\
\text { of } F\end{array}$ & $\begin{array}{c}\text { Value } \\
\text { of } p\end{array}$ & $\begin{array}{c}\text { Differences } \\
\text { between groups } \\
\text { ( } F \text { REGW) }\end{array}$ \\
$\begin{array}{l}\text { Sense of } \\
\text { comprehensibility }\end{array}$ & 1.99 & 0.096 & \\
$\begin{array}{l}\text { Sense of } \\
\text { manageability }\end{array}$ & 3.27 & 0.012 & $\begin{array}{c}\text { Difference } \\
\text { between groups } \\
2 \text { and 3; 2 and 5 }\end{array}$ \\
$\begin{array}{l}\text { Sense of } \\
\text { meaningfulness }\end{array}$ & 3.19 & 0.014 & $\begin{array}{c}\text { Difference } \\
\text { between groups } \\
\text { and 3; 2 and 5; } \\
4 \text { and 3; } 4 \text { and 5 }\end{array}$ \\
$\begin{array}{l}\text { Global sense of } \\
\text { coherence SOC }\end{array}$ & 3.52 & 0.008 & $\begin{array}{c}\text { Difference } \\
\text { between groups } \\
\text { 2 and 3; 2 and 5, } \\
4 \text { and 5 }\end{array}$ \\
\hline
\end{tabular}


According to the interpretation of the law, until 2020 an EMS physician should possess a specialisation or the title of a specialist, or complete at least the second year of specialisation in: anaesthesiology and intensive therapy, internal diseases, general or paediatric surgery, orthopaedics and traumatology of motor organs, orthopaedics and traumatology or paediatrics. In addition, the Act assumes that an EMS system physician should have 3,000 h experience in performing the occupation of a doctor in a hospital emergency department, emergency medical services team (including air services), or hospital admission department. This physician will be obliged to begin specialisation in emergency medicine before 1 January 2015 [9]. U1timately, an EMS physician will be a physician with the speciality in emergency medicine.

The effect of such a solution would be a departure from the stereotype which has been shaped for years, that an emergency medical services team within the ambulance service is the place for additional duties, where it is possible to earn extra money, especially by young physicians without professional experience and specialisation [10], which, according to Jakubaszko, could be harmful to the patients [11].

Emergency medical dispatchers indicate a considerable lack of specialists in emergency medicine, despite the fact that the number of specialists in emergency medicine in Poland is systematically increasing. In 2002, the number of physicians who obtained specialisation in emergency medicine was 5, whereas in 2008 it was 524 . According to the records kept by the Supreme Medical Council, the number of specialists in emergency medicine on 30 April 2012 was 731, including 730 who were occupationally active.

In the specialty of emergency medicine there are 806 educational places in 143 education units (state on 22 May 2012). Based on information provided by the Medical Centre for Post-Graduate Education, 481 physicians continued specialisation in emergency medicine (state as of 31 December 2011) [12].

In the Szczecin region the demand for physicians possessing this specialisation is approximately 200 [13].

According to Krystyn Sosad, a Silesian consultant for the matters of emergency medicine, in the Katowice Region, similar to other regions, specialisation places are not fully utilised. The present programme of specialisation is overloaded, exhausting, and lasts for 5 full years. The possibility should be considered to undertake an additional short path specialisation (after obtaining the specialisation in emergency medicine) in selected clinical disciplines, which undoubtedly would make this speciality more attractive [14]. This opinion is also shared by Małgorzata Popławska, director of Ambulance Services in Krakow [15].

A paramedic occupies a key place in the system of emergency medical services. A contemporary paramedic is a person with a very good education in emer- gency medicine, possessing proper psychological predispositions and specific personality. Most frequently they are passionate about their work $[14,16,17]$.

Therefore, the opinions of paramedics were investigated pertaining to the scope of problems undertaken concerning the place of a physician in an EMS team, and the need for specialisation in emergency medicine.

The results of the study are surprising. The examined group indicated paramedics as an occupational group most predisposed to performing emergency medical procedures, which seems to be a relatively courageous evaluation, resulting perhaps from the sense of high occupational prestige. Such an attitude may also evoke controversy. The role of a physician in EMS teams delivering prehospital care is indispensable in life-threatening situations, which exceed the competences of paramedics, their capabilities, and knowledge possessed concerning a given nosological unit. An important role of the physician occurs in the case of mass casualty incidents requiring comprehensive medical knowledge. The issue undertaken in the presented study becomes even more controversial as the results reveal that, according to the respondents, a paramedic with post-secondary school education is the person most suitable for the performance of lifeor health-saving procedures. The results of another scientific report showed that the general evaluation of the skills of saving life and health in emergency situations did not differ according to the level of education possessed, and oscillated on a satisfactory level; however, the satisfaction with the knowledge acquired during education was significantly higher in the group with 2-year education [18].

The respondents did not significantly differ in their opinions expressed concerning the member of the team most predisposed for the performance of life-saving procedures according to the sense of coherence and its components. In the analysis performed, the highest level of the global SOC and its components was noted in the group of paramedics who indicated a physician as the person best predisposed for undertaking life-saving procedures. Slightly lower levels were obtained in the group of respondents who mentioned a paramedic with post-secondary school education and, subsequently, a paramedic with licentiate education. Thus, it would seem that a coherent comprehension of the essence of the need for inclusion of a physician in a team expressed by the sense of coherence was obtained in the group of respondents who indicated a physician as the proper person for undertaking medical procedures, despite the earlier indications by paramedics.

The problem of specialisation of EMS physicians and their place in the emergency medical services team remains an important issue. There prevail opinions $(50.89 \%$ of the study group) that a physician 
is needed only in a specialist team - according to $42.56 \%$ of respondents in this group, specialisation in emergency medicine is necessary, while in the opinions of $8.33 \%$, specialisation is not important. In the opinions of $30.65 \%$ of respondents, a physician with specialisation in emergency medicine should be included in a team delivering prehospital care, i.e. also a basic team, and $8.04 \%$ of respondents confirmed the need for a physician irrespective of specialisation.

In order to emphasise the importance of the scope of problems concerning specialisation of EMS physicians in the opinions of paramedics, the level of the sense of coherence and its components were investigated in groups which differed with respect to their opinions concerning this issue.

The theoretical background of the concept of the sense of coherence indicates the sense of manageability as the degree to which an individual perceives the available resources as sufficient for coping with the requirements resulting from the inflowing stimuli. These are resources at the disposal solely of this individual, or at the disposal of those whom he/she trusts and can count on (spouse, friends, colleagues, God, history), whereas the sense of meaningfulness is a direct marker of the individual's will to live $[5,19]$.

Analysis of the differences between groups showed a certain regularity of the relationships, which was confirmed statistically. Lower levels of manageability, meaningfulness, and global SOC were obtained in the group of paramedics who indicated the need to include a physician in a team, irrespective of specialisation. Higher levels were observed in groups reporting the need for a physician with specialisation in emergency medicine in a specialist team, and among respondents who preferred paramedic teams.

\section{Conclusions}

The composition of an emergency medical services team still remains a disputable problem and requires further medical and legal evaluations. The assessment of the composition of a paramedical team depends on the level of education of paramedics. The need for a doctor in a team, as well as for specialization in emergency medicine, has been proven by the levels of obtained SOC and its components, together with the relations observed in groups assessing the studied problems.

\section{References}

1. European Society for Emergency Medicine. Policy Statement on Emergency Medicine in Europe. www.eusem. org/Pages/About_EUSEM/Policy_Statemrnt/Policy_Statements.html

2. Gaca M, Wiatrowski A. Realizacja programu medycyny ratunkowej w perspektywie województwa wielkopolskiego. Przew Lek 2007; 2: 240-6.

3. Rasmus A, Tosiak K. Medycyna ratunkowa i medycyna katastrof - podobieństwa i różnice. In: Medycyna ratunkowa i medycyna katastrof. Rasmus A, Gaszyński W, BalcerzakBarzdo E, Hołyński J (eds.). Polskie Towarzystwo Farmaceutyczne Oddział w Łodzi, Łódź 2003; 4-10.

4. Ustawa z dnia 8 września 2006 r. o Państwowym Ratownictwie Medycznym [Dz. U. z 2006 r. Nr 191, poz. 1410].

5. Antonovsky A. Rozwikłanie tajemnicy zdrowia. Jak radzić sobie ze stresem i nie zachorować. Instytut Psychiatrii i Neurologii, Warsaw 2005; 34-144.

6. Koniarek J, Dudek B, Makowska Z. Kwestionariusz Orientacji Życiowej. Adaptacja The Sense of Coherence Questionnaire (SOC) A. Antonovsky'ego. Przegl Psychol 1993; 4: 491-502.

7. http://m.onet.pl/biznes,1b117

8. Ustawa z dnia 22.10.2010 r. o zmianie ustawy o Państwowym Ratownictwie Medycznym oraz niektórych innych ustaw. Dziennik Ustaw Nr 219.

9. Ustawa z dnia 23 listopada 2012 r. o zmianie Ustawy o Państwowym Ratownictwie Medycznym.

10.Leki K. Państwowe Ratownictwo Medyczne - plusy i minusy nowych regulacji systemu. Na Ratunek 2007; 1: 10-12.

11.http://prawo.rp.pl

12.http://www.sejm.gov.pl/sejm7.nsf/InterpelacjaTresc. $\mathrm{xsp}$ ?key=0E9AD6D0

13.http://24kurier.pl/Aktualnosci/Szczecin/Odkladanie-problemu

14. Bętkowska-Bielach B. Śląsk wzorem dla innych województw! Na Ratunek 2012; 1: 38-40.

15.http://www.studencimedycyny.pl/a/Nadal_brakuje_lekarzy_medycyny_ratunkowej-429

16.Goniewicz M. Kształcenie ratowników medycznych w Akademii Medycznej im. Prof. Feliksa Skubiszewskiego w Lublinie. In: Ratownik medyczny problemy edukacyjne i organizacyjno-prawne. Konieczny J (ed.). Garmond Oficyna Wydawnicza, Poznan 2006; 31-9.

17. Wołoszyn P. Ratownicy medyczni jako grupa społeczna. Na Ratunek 2008; 2: 21-5.

18. Rębak D. Przygotowanie ratowników medycznych do pełnienia funkcji zawodowych w świetle dwoistego systemu kształcenia. Studia Medyczne 2012; 25: 43-50.

19. Heszen I. Sęk H. Psychologia zdrowia. Wydawnictwo Naukowe PWN, Warszawa 2007; 79-83.

\section{Address for correspondence:}

Dorota Rębak PhD

Department of Surgery and Surgical Nursing

with Research Laboratory

Faculty of Health Sciences

Jan Kochanowski University

al. IX Wieków Kielc 19, 25-317 Kielce, Poland

Phone: +48 501321304

Fax: +48 413496916

E-mail: dorotar@ujk.edu.pl 